\title{
Challenges on the provision of palliative care for patients with cancer in low- and middle-income countries: a systematic review of reviews
}

\author{
Hammoda Abu-Odah, Alex Molassiotis ${ }^{*}$ and Justina Liu
}

\begin{abstract}
Background: Despite the significant benefits of palliative care $(P C)$ services for cancer patients, multiple challenges hinder the provision of PC services for these patients. Low- and middle-income countries (LMICs) are witnessing a sharp growth in the burden of non-communicable diseases. There is a significant gap between demand and supply of PC in LMICs in current health services. This review aims to synthesise evidence from previous reviews and deliver a more comprehensive mapping of the existing literature about personal, system, policy, and organisational challenges and possible facilitators on the provision of PC services for cancer patients in LMICs.

Methods: A systematic review of reviews was performed following PRISMA guidelines. PubMed, EMBASE, SCOPUS, PsycINFO, Web of Sciences, CINAHL, and Cochrane Library databases were searched to identify review papers published between 2000 and 2018 that considered challenges and possible facilitators to PC provision. A modified socioecological model was used as a framework for analysing and summarising findings.

Results: Fourteen reviews were included. The reviews varied in terms of aim, settings, and detail of the challenges and possible facilitators. The main challenges of personal and health care systems included knowledge deficits and misunderstandings from patients, families, the general public, and health care providers about PC; and inadequate number of trained workforce. Besides, limited physical infrastructure, insufficient drugs for symptom relief and lack of a comprehensive national plan for implementing PC were the core organisational and policy level challenges that were recognised. Furthermore, the main possible facilitators that were identified included provision of adequate training for health care providers and health education for patients, families and the general public to enhance their knowledge, beliefs, and attitudes to PC. Finally, involvement of policymakers and making drugs available for symptom relief should also be in place to improve the health care systems.
\end{abstract}

Conclusions: Understanding challenges to the provision of PC for people with cancer could help in the development of a PC pathway in LMICs. This knowledge could be used as a guide to develop an intervention programme to improve PC. Political influence and support are also required to ensure the sustainability and the provision of high-quality PC.

Keywords: Cancer, Challenges to care, Low-income countries, Middle-income countries, Palliative care

\footnotetext{
*Correspondence: alex.molasiotis@polyu.edu.hk

School of Nursing, The Hong Kong Polytechnic University, Kowloon, Hong Kong

C C The Author(s). 2020 Open Access This article is licensed under a Creative Commons Attribution 4.0 International License, which permits use, sharing, adaptation, distribution and reproduction in any medium or format, as long as you give appropriate credit to the original author(s) and the source, provide a link to the Creative Commons licence, and indicate if changes were made. The images or other third party material in this article are included in the article's Creative Commons licence, unless indicated otherwise in a credit line to the material. If material is not included in the article's Creative Commons licence and your intended use is not permitted by statutory regulation or exceeds the permitted use, you will need to obtain permission directly from the copyright holder. To view a copy of this licence, visit http://creativecommons.org/licenses/by/4.0/ The Creative Commons Public Domain Dedication waiver (http://creativecommons.org/publicdomain/zero/1.0/) applies to the data made available in this article, unless otherwise stated in a credit line to the data.
} 


\section{Background}

Cancer includes more than 100 different diseases of unknown aetiology [1]. It is an increasingly significant reason for morbidity and mortality all over the world [2]. In 2018, about 18.1 million new cases of cancer were diagnosed globally [3]. In the same year, cancer accounts for about 9.6 million deaths; $70 \%$ of deaths are registered in low- and middle-income countries [3]. Low-and middleincome countries (LMICs), as defined by the World Bank, are countries whose Gross National Income ranges between $\$ 996$ and $\$ 3895$ [4]. These countries are experiencing an increase in the burden of noncommunicable diseases, including cancer [3]. By 2035, about two-thirds of new cancer cases will be diagnosed in LMICs [5]. This will put enormous pressures and strain on the health care systems of LMICs [6] as most of these countries are not well-prepared and organised to manage this growing burden and suffer from insufficient budget allocation and limited resources [7]. Treating such diseases place high demands on health services in countries with scarce resources resulting in high direct and indirect costs of care.

The consequences of cancer and its treatments have been significant on the quality of life (QOL) of patients and their families $[8,9]$. The diagnosis of cancer frequently results in a complex set of issues that patients and their families must confront [10]. Alleviating the consequences of cancer and providing high-quality of care, including symptom management, handling side effects, as well as social, psychological, spiritual and emotional support are recognised as high priority aspects that should be taken into account [11]. These aspects are categorised under the PC umbrella [12, 13].

Palliative care $(\mathrm{PC})$ is considered one of the most holistic and appropriate approaches to provide specialised medical and nursing care for patients with chronic illnesses [14] and makes the lives of patients with advanced diseases to be meaningful and productive. The 2002 WHO definition of PC states that "PC is an approach that improves the quality of life of patients and their families through the prevention and relief of suffering by means of early identification and impeccable assessment and treatment of pain and other problems, physical, psychosocial and spiritual" [12, 13, 15] (p.84, ref. [15]). PC is intended to relieve symptoms that appear when cancer is progressing and allow patients to live comfortably rather than cure the disease $[3,16]$. Due to a transitional demographic change in population growth in the world and increase in life expectancy, the need for PC has increased, and the application of this approach is urgently required to be adopted [17].

Palliative care is a holistic approach focusing on all patients with all incurable diseases $[18,19]$, but PC programs in many countries start with cancer patients as this is the largest group of of patients with life-limiting diseases and are often admitted at the hospital for an extended period [20]. Long term admissions create pressures on a country's health care system especially when confined with a lack of budget allocation, limited resources, and lack advanced technologies for cancer detection and treatment [7]. Almost all of the cancer patients in LMICs are diagnosed at a late stage, making them more inclined to experience severe pain and distress $[21,22]$, respiratory and gastrointestinal problems, and loss of consciousness, all related to disease progression [23]. Considering that, patients with cancer are in a high priority in need of PC at the end-stage-of-life. Also, being the largest group, it is often the focus when countries develop their PC programmes, before introducing it into other groups of patients with end of life and PC needs [24]. While it is acknowledged that there is an ethical imperative to provide PC for all patients with incurable and life-limiting illnesses and that the PC priorities, particularly in the African continent, may be related more to treating patients with HIV/AIDS and related comorbidities and co-diseases, the focus of this paper is on cancer patients for two reasons. Firstly, cancer rates, particularly in Africa, are expected to grow by $400 \%$ over the next 50 years [25], $70 \%$ of cancer deaths take place in LMICs and 70\% of patients diagnosed with cancer in LMICs are diagnosed at a very advanced stage $[2,3,26]$. Secondly, this review is an initial stage of a larger project that is developed to address some of the key issues around implementing a PC programme in Palestine. In the context of Palestine, cancer is the second leading cause of death (at 14\%) with an expected high increase in the cancer burden that will create challenges in the delivery of care to patients that are mostly diagnosed at a late stage [27]. The African Palliative Care Association has recently also advocated for more PC to be provided to cancer patients and more access to opioids and other essential medicines [28].

Although PC has become a significant approach to improving the QOL of patients worldwide, only 3 million out of 20 million patients with a life-threatening illness in the world receive PC services. Most of these services are available and provided in developed countries [24]. In many LMICs, PC services are not available, and this is attributed to multiple challenges that continue to create obstacles to their availability and implementation. For instance, most PC models that exist are developed and implemented in Western countries [29, 30], and may not be congruent with some cultural issues (e.g., religion, beliefs, and norms) in other countries. Health care provider (HCP)-related issues, such as training and education, are other obstacles preventing the adoption of PC [31-34] in LMICs. Besides, related administrative matters, such as access to opioids [31, 32, 35] and 
unwillingness of patients and families to be referred to specialised PC units may also prevent the adoption of PC services.

Some action measures have been undertaken by WHO to promote and implement $\mathrm{PC}$ in the health care systems of LMICs [36]. However, these measures have faced many obstacles during implementation. LMICs are experiencing a significant gap between demand and supply of PC services, and therefore, immediate actions are required to overcome these impediments [37]. The urgency is heightened by the fact that most cancer patients in LMICs are diagnosed during the late-stage of the disease and, therefore, they are in desperate need of adequate PC [38].

A number of studies have been conducted worldwide to assess the challenges of dispensing PC services. Donkor et al., [39] assessed challenges in LMICs, Fadhil et al., [40] focused on similar issues in the Eastern Mediterranean region, and Aldridge et al., [41] focused on challenges to integrating PC in the USA. These studies focused generally on patients with life-threatening diseases with limited attention given to cancer patients. However, no systematic overview synthesising the challenges and possible facilitators on the provision of $\mathrm{PC}$ in LMICs has been reported.

Therefore, this current systematic review is conducted to synthesise evidence from previous literature and provide a comprehensive mapping of the existing literature about challenges and possible facilitators in the provision of PC for cancer patients in LMICs. The methodology utilised is based on the socio-ecological model (SEM) [42]. This model is widely used across studies for having multilevel determinants [43, 44]. It has four levels; personal level; organisational level; health system level; and policy/payment level (Fig. 1). An intensive and comprehensive search of seven databases has been carried out with focus on patients with cancer in LMICs. This paper seeks to answer the following questions: (1) what are the challenges associated with the provision of PC for cancer patients in LMICs? And (2) what are the possible facilitators that can overcome these challenges?

\section{Methods}

Study design

This is a systematic review of reviews aimed at providing a broad overview of the field, and mapping the current body of work on challenges of providing PC services to cancer patients. This review is structured in accordance with the PRISMA (preferred reporting items for systematic reviews and meta-analyses) guidance [45].

\section{Search sources and strategies}

Searches were performed on seven electronic databases: PubMed, EMBASE, SCOPUS, PsycINFO, Web of Sciences, Cumulative Index to Nursing and Allied Health Literature (CINAHL), and Cochrane Database of Systematic Reviews. The search was specific to review articles published in English language in or after 2000 to

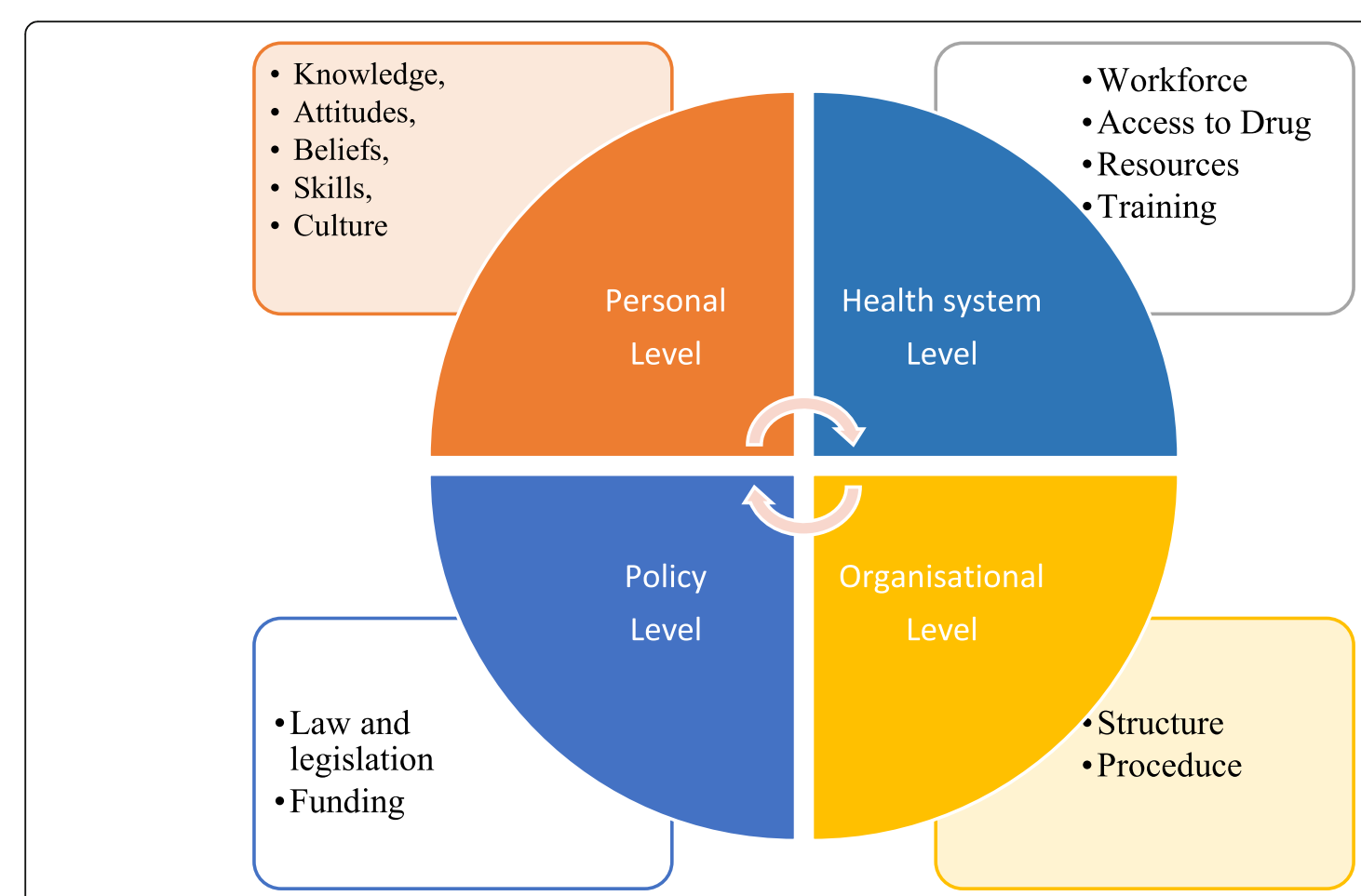

Fig. 1 A modified socioecological framework [42] 
capture information more relevant to current health care systems, and given that PC is defined by WHO in 1998 and optimised in 2002 [12].

The search strategy of this systematic review is based on the PCC (population, concept, and context) framework. The following terms are included in the search strategy; first, terms for "challenges", such as "barriers", "problems", "limitations", and "obstacles" were included. Second, words synonymous to "provision", such as "bringing", and "access" were also added in the search. Third, terms like "palliative care", such as "palliative medicine", "hospice care", "supportive care", "terminal care", and "end-of-life care" were further added. Fourth, terms for "cancer", such as "tumor", "neoplasms", "terminal cancer", "metastatic cancer" and "malignant" were included. Finally, expressions for "review" were included. All these terms were linked using the Boolean operator "AND" and Medical Subject Heading (MeSH) terms were used. Table 1 shows the detailed search terms for PubMed and CINAHL databases adjusted appropriately for the other databases.

\section{Criteria for considering studies in this review Inclusion criteria}

- Review articles only;

- Review focusing on patients diagnosed with cancer;

- Review focusing on LMICs;

- Review focusing on patients aged at least 18 years, or the words 'adults' are used by authors in the description of the samples;

- Published in journals in or after 2000; and

- Written in English.

\section{Exclusion criteria}

- Informal literature review (review does not have defined research questions and does not have defined search process) or discussion papers;

- Studies with non-cancer diseases or mixed populations without provision of separate results for cancer patients; and

- Protocols, editorial comments, conference abstracts, guidelines, and policies

\section{Study selection and data extraction}

The retrieved studies were exported into Endnote version $\mathrm{X} 9$, which was subsequently used to remove duplicates. Titles and abstracts of the remaining studies were screened by the first author (HAO) for eligibility against the inclusion and exclusion criteria. Full text of potentially eligible studies was then located for further screening. The second author (AM) was responsible for making the final decision of any uncertainly that the first author encountered during the assessment of full text papers. Reasons for excluding reviews were identified and documented.

For each included study, data were extracted by one author (HAB) and reviewed by a second author (AM) if needed. A data extraction sheet was utilised to record the following data; (1) citation details: authors, year of publication, and country of the first author; (2) number of studies included and sample descriptions; (3) aim(s) of the review; (4) results (main findings) summarised based on the SEM; (4.1) category of challenges; personal, system, policy and organisational factors, (4.2) category of possible facilitators; personal, system, policy and organisational factors (Table 2).

\section{Quality assessment of the reviews}

Two authors independently used the Assessment of Multiple Systematic Reviews (AMSTAR-2) tool for systematic review articles or the International Narrative Systematic Assessment (INSA) tool for narrative review articles [54] to assess the quality of all included review articles. AMSTAR-2 has 16 items; each item is rated as 'yes' for a positive result or 'no' for no information provided or 'partial yes' response in some cases where we consider it useful to determine partial compliance with the standard. The overall quality of a systematic review has been rated as 'high', 'moderate', 'low' and 'critically low' [55]. High quality means that the paper provides comprehensive summary of the results of the available studies; moderate-quality indicates that the review paper has more than one weakness, but no critical flaws; while low quality shows that the paper has a critical flaw and may not provide an accurate and comprehensive summary of the available studies [55]. INSA contains seven items which include clarity of background, objective, conclusion, description of selection of studies, study characteristics, results, and conflict of interest. Each item is graded as 'yes' or 'no' and one point is given for each of the seven criteria. A review with a total INSA score of $\geq 5$ points is considered a 'good' quality review [54].

\section{Data analysis}

As mentioned, the SEM was selected as an analytical framework for data analysis (Fig. 1). The McLeroy et al. model that is generated from the SEM was adopted to align the context and to conceptualize the review findings [42]. This is done to remove distinction between intrapersonal and interpersonal domains and, in its place, differentiate between HCP, patient and caregiver domains. Furthermore, the model is appraised to identify community domains as health system domains [42]. Therefore, the final modified model has four levels; 1 ) personal level; 2) organisational level; 3) health system level; 4) policy/payment level. The personal level focuses 
Table 1 Selected Search Strategies for review articles

\begin{tabular}{|c|c|c|}
\hline Searc & Search Term & Hits \\
\hline \multicolumn{3}{|c|}{ PubMed } \\
\hline S1 & $\begin{array}{l}\text { Search ((((challenges [Title/Abstract]) OR obstacles [Title/Abstract]) OR limitations [Title/Abstract]) OR problems [Title/Abstract]) OR } \\
\text { barriers [Title/Abstract] }\end{array}$ & $\begin{array}{l}1,051, \\
391\end{array}$ \\
\hline S2 & Search ((provision [Title/Abstract]) OR bringing [Title/Abstract]) OR access [Title/Abstract] & 350,573 \\
\hline S3 & $\begin{array}{l}\text { Search (((((palliative care [MeSH Terms]]) OR palliative medicine [Title/Abstract]) OR hospice care [Title/Abstract]) OR supportive care } \\
\text { [Title/Abstract]) OR terminal care [Title/Abstract]) OR end of life care [Title/Abstract] }\end{array}$ & 72,182 \\
\hline S4 & $\begin{array}{l}\text { Search (((((cancer [Title/Abstract]) OR tumor [Title/Abstract]) OR neoplasms [Title/Abstract]) OR terminal cancer [Title/Abstract]) OR } \\
\text { metastatic cancer [Title/Abstract]) OR malignant [Title/Abstract] }\end{array}$ & $\begin{array}{l}2,462, \\
108\end{array}$ \\
\hline S5 & Search review*[Title/Abstract] Sort by: Best Match & $\begin{array}{l}1,878, \\
924\end{array}$ \\
\hline S6 & S1 AND S2 AND S3 AND S4 AND S5 & 88 \\
\hline S7 & S1 AND S2 AND S3 AND S4 AND S5 (Limiters - Date of Publication: 20000101-20,190,110; English Language) & 79 \\
\hline \multicolumn{3}{|c|}{ CINAHL } \\
\hline S1 & TI challenges OR TI barriers OR TI problems OR TI limitations OR TI obstacles & 68,419 \\
\hline S2 & $A B$ challenges $O R A B$ barriers $O R A B$ problems $O R$ AB limitations $O R A B$ obstacles & 373,747 \\
\hline S3 & $A B$ provision $O R A B$ bringing $O R A B$ access & 110,926 \\
\hline S4 & TI provision OR TI bringing OR TI access & 30,549 \\
\hline S5 & TI palliative care OR TI palliative medicine OR TI hospice care OR TI supportive care OR TI terminal care OR TI end of life care & 22,990 \\
\hline S5 & $A B$ palliative care $O R A B$ palliative medicine $O R A B$ hospice care $O R A B$ supportive care $O R A B$ terminal care $O R A B$ end of life care & 25,576 \\
\hline S7 & $A B$ cancer $O R A B$ tumor $O R A B$ neoplasms $O R A B$ terminal cancer $O R A B$ metastatic cancer $O R A B$ malignant & 270,124 \\
\hline S8 & TI cancer OR TI tumor OR TI neoplasms OR TI terminal cancer OR TI metastatic cancer OR TI malignant & 252,261 \\
\hline 59 & Tl review* & 176,934 \\
\hline S10 & AB review* & 366,746 \\
\hline S11 & S1 OR S2 & 416,347 \\
\hline S12 & S3 OR S4 & 130,606 \\
\hline S13 & S5 OR S6 & 37,837 \\
\hline S14 & S7 OR S8 & 392,676 \\
\hline S15 & S9 OR S10 & 473,045 \\
\hline S16 & S11 AND S12 AND S13 AND S14 AND S15 & 74 \\
\hline S17 & S11 AND S12 AND S13 AND S14 AND S15 (Limiters - Date of Publication: 20000101-20,190,110; English Language) & 71 \\
\hline
\end{tabular}

Explanation of abbreviations: S Search; MeSH Medical Subject Headings; AB Abstract; TI Title

on patients, families, and HCPs, while the organisational level deals with the culture of the organisation and infrastructure. The health care system level describes workforce and training, and finally the policy/payment level relates to legislation and funding.

\section{Results}

\section{Characteristics of the included reviews}

The review yielded 723 articles, and 11 met inclusion criteria. Each review reference list was further assessed to see if any relevant review has been omitted. Through this, an additional three reviews were added. Consequently, 14 reviews are included for analysis (Fig. 2).

The majority of the included studies $(n=12)$ were narrative reviews $[32-35,40,46,47,49-53]$, and the remaining two were systematic reviews [39, 48]. Concerning the geographical focus of the reviews, reviews $(n=4)$ originated from Middle Eastern countries [34, 40, $49,52]$ and LMICs $(n=3)[33,35,39]$. The other seven reviews focused on specific countries including Jordan [32], Latin America [46], Indonesia [48], Turkey [50], India [53], Palestine [51], and Kenya [47].

With regards to the origin of the authors, seven authors were from developed countries $[33,35,39,46,49$, $52,53]$; including two from the USA $[35,46]$, two from the UK [52, 53], and one each from Australia [39], Canada [33] and Israel [49]. As for the year of publication, the number of publications increased significantly in the last 4 years [32, 33, 39, 40, 46-48]. Only two reviews were published before 2010 [52, 53].

In terms of disease category, 13 reviews focused on patients diagnosed with cancer [32-35, 39, 40, 46, 47, 49-53], and one review focused on mixed chronic diseases, including cancer [48]. Concerning the number of studies 
Table 2 Summary of aims and key findings of the included reviews

\begin{tabular}{|c|c|c|c|c|}
\hline \multirow{2}{*}{$\begin{array}{l}\text { Author (Year), } \\
\text { Implementation } \\
\text { Year(s), Country/ } \\
\text { Region } \\
\end{array}$} & \multirow[t]{2}{*}{ Review aim } & \multirow{2}{*}{$\begin{array}{l}\text { Setting/ } \\
\text { Population }\end{array}$} & \multicolumn{2}{|l|}{ Findings } \\
\hline & & & Barriers & $\begin{array}{l}\text { Possible facilitators/recommendations for } \\
\text { improvement }\end{array}$ \\
\hline $\begin{array}{l}\text { Donkor, Luckett, } \\
\text { Aranda and Phillips } \\
\text { [39], } \\
\text { 1990-2017 } \\
\text { Australia } \\
\text { Systematic review, } \\
\text { included } 18 \text { studies }\end{array}$ & $\begin{array}{l}\text { To identify the } \\
\text { facilitators } \\
\text { and barriers to the } \\
\text { implementation of } \\
\text { cancer } \\
\text { treatments and PC. }\end{array}$ & $\begin{array}{l}\text { LMICs } \\
\text { Cancer }\end{array}$ & $\begin{array}{l}\text { Health system: } \\
\text { - Drug importation process } \\
\text { Policy: } \\
\text { - Lack of financial support } \\
\text { - Limited political commitment } \\
\text { - Restrictive pharmacovigilance } \\
\text { laws and regulations } \\
\text { - Fragmented health system } \\
\text { Organisation/ structure: } \\
\text { - Limited physical infrastructure }\end{array}$ & $\begin{array}{l}\text { Personal: } \\
\text { - Education } \\
\text { - Community sharing } \\
\text { Health system: } \\
\text { - Creating a learning environment } \\
\text { - Information management system } \\
\text { Policy: } \\
\text { - Payment support } \\
\text { - Stakeholder sharing } \\
\text { - Political commitment } \\
\text { - Positive relationships with international } \\
\text { organisations } \\
\text { - Strategy aligned with national policy }\end{array}$ \\
\hline $\begin{array}{l}\text { Soto-Perez-de-Celis } \\
{[46]} \\
2017 \\
\text { USA }\end{array}$ & $\begin{array}{l}\text { To identify the } \\
\text { existing } \\
\text { deficiencies and } \\
\text { providing } \\
\text { a framework for } \\
\text { the improvement } \\
\text { of PC. }\end{array}$ & $\begin{array}{l}\text { Latin America } \\
\text { Cancer }\end{array}$ & $\begin{array}{l}\text { Personal: } \\
\text { - Cultural barriers } \\
\text { Health System: } \\
\text { - Lack of opportunities for clinical } \\
\text { training } \\
\text { Policy: } \\
\text { - Inadequate or inappropriate } \\
\text { legislation } \\
\text { - Lack of comprehensive national } \\
\text { PC plans } \\
\text { - Unreliable reporting of data } \\
\text { Organisation/ Structure: } \\
\text { - Insufficient infrastructure }\end{array}$ & $\begin{array}{l}\text { Personal: } \\
\text { - Improve education } \\
\text { - Enhance cultural aspects } \\
\text { - Individualized care for patient's preferences and } \\
\text { beliefs } \\
\text { Health System: } \\
\text { - Increase the availability of pain medication } \\
\text { - Training to all HCPs } \\
\text { - Enhance, expand access to medication } \\
\text { Policy: } \\
\text { - Design comprehensive PC plans } \\
\text { - Integrate end-of-life care into national health care } \\
\text { laws } \\
\text { - Enhance research } \\
\text { Organisation/ Structure: } \\
\text { - Improve infrastructure }\end{array}$ \\
\hline $\begin{array}{l}\text { Fadhil et al. [40] } \\
2017 \\
\text { Egypt }\end{array}$ & $\begin{array}{l}\text { To identify barriers } \\
\text { to } \\
\text { the development } \\
\text { of } P C \text {. }\end{array}$ & $\begin{array}{l}\text { Eastern } \\
\text { Mediterranean } \\
\text { Region } \\
\text { Cancer }\end{array}$ & $\begin{array}{l}\text { Personal: } \\
\text { - Poor awareness of policy } \\
\text { makers about PC } \\
\text { - Poor awareness of HCPs about } \\
\text { PC } \\
\text { - Poor public awareness } \\
\text { Health System: } \\
\text { - Little partnership working } \\
\text { - Insufficient PC education for } \\
\text { HCPs } \\
\text { - Gaps in access to essential pain- } \\
\text { relief medicines. } \\
\text { Policy: } \\
\text { - Scarcity of national plans and } \\
\text { policies } \\
\text { - Complicated political situations } \\
\text { - Weak health-care systems } \\
\text { - Absence of PC in national } \\
\text { policies }\end{array}$ & - \\
\hline $\begin{array}{l}\text { Ali [47] } \\
2016 \\
\text { Kenya }\end{array}$ & $\begin{array}{l}\text { To assess the } \\
\text { integration } \\
\text { of PC services into } \\
\text { the public } \\
\text { healthcare system }\end{array}$ & $\begin{array}{l}\text { Kenya } \\
\text { cancer }\end{array}$ & - & $\begin{array}{l}\text { Health system: } \\
\text { - Training HCPs } \\
\text { - A higher diploma in PC } \\
\text { Policy: } \\
\text { - The government budget for PC services } \\
\text { - Include PC in local health strategies and plans. } \\
\text { - National PC guidelines }\end{array}$ \\
\hline $\begin{array}{l}\text { Hannon et al. [33] } \\
2015 \\
\text { Canada }\end{array}$ & $\begin{array}{l}\text { To overcome } \\
\text { barriers } \\
\text { that continue to } \\
\text { affect } \\
\text { the availability of } \\
\text { PC in LMICs. }\end{array}$ & $\begin{array}{l}\text { LMICs } \\
\text { cancer }\end{array}$ & $\begin{array}{l}\text { Personal: } \\
\text { - Negative attitudes about PC } \\
\text { and death and dying } \\
\text { Health System: } \\
\text { - Limited access to opioid } \\
\text { medication } \\
\text { - Lack of training of HCPs and } \\
\text { volunteers }\end{array}$ & $\begin{array}{l}\text { Personal: } \\
\text { - Education of HCPs } \\
\text { - Shifts in societal norms to PC } \\
\text { - Shifts in HCPs norms to PC } \\
\text { Health System: } \\
\text { - Changes in legislation restricting access to opioid } \\
\text { medications } \\
\text { - Training of health professionals; }\end{array}$ \\
\hline
\end{tabular}


Table 2 Summary of aims and key findings of the included reviews (Continued)

\begin{tabular}{|c|c|c|c|c|}
\hline \multirow{2}{*}{$\begin{array}{l}\text { Author (Year), } \\
\text { Implementation } \\
\text { Year(s), Country/ } \\
\text { Region }\end{array}$} & \multirow[t]{2}{*}{ Review aim } & \multirow{2}{*}{$\begin{array}{l}\text { Setting/ } \\
\text { Population }\end{array}$} & \multicolumn{2}{|l|}{ Findings } \\
\hline & & & Barriers & $\begin{array}{l}\text { Possible facilitators/recommendations for } \\
\text { improvement }\end{array}$ \\
\hline & & & $\begin{array}{l}\text { Policy: } \\
\text { - Lack of investment in health } \\
\text { systems }\end{array}$ & $\begin{array}{l}\text { Policy: } \\
\text { - A health policy that supports the integration of } \\
\text { PC } \\
\text { - Investment in systems of health care delivery } \\
\text { - Development of rigorous data and research } \\
\text { - International partnerships }\end{array}$ \\
\hline $\begin{array}{l}\text { Rochmawati et al. } \\
\text { [48] } \\
\text { 1990-2015 } \\
\text { Indonesia } \\
\text { Systematic review, } \\
\text { includes } 9 \text { studies }\end{array}$ & $\begin{array}{l}\text { To identify } \\
\text { facilitators } \\
\text { and barriers to } \\
\text { the provision of } \\
\text { PC. }\end{array}$ & $\begin{array}{l}\text { Indonesia } \\
\text { Cancer, HIV/ } \\
\text { AIDS }\end{array}$ & $\begin{array}{l}\text { Personal: } \\
\text { - Knowledge deficit and } \\
\text { misunderstanding of HCPS } \\
\text { Health System: } \\
\text { - Difficult access to narcotic } \\
\text { drugs } \\
\text { Organisation/ Structure: } \\
\text { - Geography }\end{array}$ & $\begin{array}{l}\text { Personal: } \\
\text { - Family and community support } \\
\text { Policy: } \\
\text { - Policy and organisation support } \\
\text { Health System: } \\
\text { - Volunteering }\end{array}$ \\
\hline $\begin{array}{l}\text { Abdel-Razeq et al. } \\
\text { [32] } \\
2014 \\
\text { Jordan }\end{array}$ & $\begin{array}{l}\text { To discuss } \\
\text { challenges } \\
\text { and offer } \\
\text { suggestions } \\
\text { for the } \\
\text { improvement } \\
\text { of cancer } \\
\text { management. }\end{array}$ & $\begin{array}{l}\text { Jordan } \\
\text { Cancer }\end{array}$ & $\begin{array}{l}\text { Personal: } \\
\text { - Negative HCPs attitudes } \\
\text { - Negative public attitudes } \\
\text { Health System: } \\
\text { - Lack of specialized human } \\
\text { resources } \\
\text { - Lack of adequate training of } \\
\text { responsible staff } \\
\text { - Interrupted opioids supply and } \\
\text { availability } \\
\text { - Shortage of trained female } \\
\text { nurses } \\
\text { - Few specialized ancillary } \\
\text { support personnel } \\
\text { Policy: } \\
\text { - Not available outcome data at a } \\
\text { national level }\end{array}$ & $\begin{array}{l}\text { Personal: } \\
\text { - Increase HCPs knowledge } \\
\text { Health System: } \\
\text { - Structured training programs for HCPs } \\
\text { Policy: } \\
\text { - Integration of both clinical care and clinical } \\
\text { research }\end{array}$ \\
\hline $\begin{array}{l}\text { Zeinah et al. [34] } \\
2012 \\
\text { Qatar }\end{array}$ & $\begin{array}{l}\text { To outline current } \\
\text { PC at Middle } \\
\text { Eastern countries. } \\
\text { To address major } \\
\text { challenges } \\
\text { hindering } \\
\text { the development } \\
\text { of PC. }\end{array}$ & $\begin{array}{l}\text { Middle East } \\
\text { countries } \\
\text { Cancer }\end{array}$ & $\begin{array}{l}\text { Personal: } \\
\text { - Lack of education and } \\
\text { awareness } \\
\text { Health System: } \\
\text { - Shortage of specialized PC } \\
\text { teams } \\
\text { Policy: } \\
\text { - Political issues } \\
\text { - Scarcity of resources } \\
\text { - Shortage or lack of funding } \\
\text { - Lack or deficiency } \\
\text { governmental support } \\
\text { Organisation/ Structure: } \\
\text { - No application of service } \\
\text { (including opioid use and } \\
\text { expertise) }\end{array}$ & $\begin{array}{l}\text { Personal: } \\
\text { - Raising awareness of the public on opiophobia; } \\
\text { - Raising awareness of the HCPs on opiophobia. } \\
\text { Health System: } \\
\text { - Informal training to medical oncologists in PC. } \\
\text { - Providing formal education to HCPs } \\
\text { Policy: } \\
\text { - Adequate funding for training programs. }\end{array}$ \\
\hline $\begin{array}{l}\text { Basu et al. [35] } \\
2013 \\
\text { USA }\end{array}$ & $\begin{array}{l}\text { To provide an } \\
\text { overview } \\
\text { of the progress in } \\
\text { providing PC in } \\
\text { low- and } \\
\text { medium-resource } \\
\text { countries. } \\
\text { To present the } \\
\text { development of } \\
\text { PC in Ethiopia. }\end{array}$ & $\begin{array}{l}\text { LMICs } \\
\text { Cancer }\end{array}$ & $\begin{array}{l}\text { Personal: } \\
\text { - Negative cultural attitudes and } \\
\text { beliefs of patients } \\
\text { - Negative cultural attitudes of } \\
\text { physicians } \\
\text { Health System: } \\
\text { - Lack of a trained workforce; } \\
\text { - Lack of availability of opioids or } \\
\text { restricting in their use } \\
\text { Policy: } \\
\text { - Lack of funding }\end{array}$ & - \\
\hline $\begin{array}{l}\text { Silbermann et al. [49] } \\
2012 \\
\text { Israel }\end{array}$ & $\begin{array}{l}\text { To address the } \\
\text { accomplishments } \\
\text { and } \\
\text { challenges of }\end{array}$ & $\begin{array}{l}\text { Middle East } \\
\text { countries } \\
\text { Cancer }\end{array}$ & $\begin{array}{l}\text { Personal: } \\
\text { - Families' feeling of alienation } \\
\text { and isolation } \\
\text { - Families' fear of neglect by the }\end{array}$ & $\begin{array}{l}\text { Personal: } \\
\text { - Education of physicians and nurses about PC } \\
\text { principles } \\
\text { - A community-based orientation }\end{array}$ \\
\hline
\end{tabular}


Table 2 Summary of aims and key findings of the included reviews (Continued)

\begin{tabular}{|c|c|c|c|c|}
\hline \multirow{3}{*}{$\begin{array}{l}\text { Author (Year), } \\
\text { Implementation } \\
\text { Year(s), Country/ } \\
\text { Region }\end{array}$} & \multirow[t]{2}{*}{ Review aim } & \multirow{2}{*}{$\begin{array}{l}\text { Setting/ } \\
\text { Population }\end{array}$} & \multicolumn{2}{|l|}{ Findings } \\
\hline & & & Barriers & $\begin{array}{l}\text { Possible facilitators/recommendations for } \\
\text { improvement }\end{array}$ \\
\hline & $\begin{array}{l}\text { palliative } \\
\text { cancer care in } \\
\text { Middle } \\
\text { Eastern countries. }\end{array}$ & & $\begin{array}{l}\text { primary physician } \\
\text { Health System: } \\
\text { - Lack of relevant training of } \\
\text { HCPs } \\
\text { - Poor accessibility to essential PC } \\
\text { drugs } \\
\text { - Delay in referrals } \\
\text { Policy: } \\
\text { - Lack of health policies and } \\
\text { plans }\end{array}$ & $\begin{array}{l}\text { Health System: } \\
\text { - Introduce PC principles into the curricula } \\
\text { - Develop postgraduate training programs for } \\
\text { physicians and nurses. } \\
\text { Policy: } \\
\text { - Public policy }\end{array}$ \\
\hline $\begin{array}{l}\text { Elcigil [50] } \\
2011 \\
\text { Turkey }\end{array}$ & $\begin{array}{l}\text { To assess the } \\
\text { status of PC in } \\
\text { Turkey. }\end{array}$ & $\begin{array}{l}\text { Turkey } \\
\text { Cancer }\end{array}$ & $\begin{array}{l}\text { Personal: } \\
\text { - Lack of PC education } \\
\text { - Lack of public awareness } \\
\text { - Limited knowledge of opioid } \\
\text { analgesics } \\
\text { Health System: } \\
\text { - Lack of training programs } \\
\text { - Shortage of nursing staff } \\
\text { - Lack of certification for PC } \\
\text { Nursing } \\
\text { Policy: } \\
\text { - Very limited research }\end{array}$ & $\begin{array}{l}\text { Personal: } \\
\text { - Increase public awareness channels } \\
\text { Health System: } \\
\text { - Disseminate information on certification of PC } \\
\text { nurses to agencies. } \\
\text { Policy: } \\
\text { - Establish interdisciplinary research on PC concepts } \\
\text { - Increase funding for research } \\
\text { - Evidence-based curriculum to strengthen the } \\
\text { teaching of PC concepts }\end{array}$ \\
\hline $\begin{array}{l}\text { Shawawra and Khleif } \\
{[51]} \\
2011 \\
\text { Palestine }\end{array}$ & $\begin{array}{l}\text { To conduct a } \\
\text { needs } \\
\text { assessment survey } \\
\text { within } \\
\text { facilities that } \\
\text { provide } \\
\text { care for oncology } \\
\text { patients in the } \\
\text { West Bank. }\end{array}$ & $\begin{array}{l}\text { Palestine } \\
\text { Cancer }\end{array}$ & $\begin{array}{l}\text { Personal: } \\
\text { - Lack of community awareness } \\
\text { on PC } \\
\text { Health System: } \\
\text { - No presence of educational } \\
\text { resources for PC, } \\
\text { - No training programs in PC, } \\
\text { Policy: } \\
\text { - An absence of organisational } \\
\text { strategic planning, } \\
\text { - No standards for PC service } \\
\text { - An absence of national } \\
\text { standards on PC. }\end{array}$ & $\begin{array}{l}\text { Personal: } \\
\text { - The need for public awareness. } \\
\text { Health System: } \\
\text { - The need for training of HCPs } \\
\text { - Introduce PC principles into the curricula } \\
\text { Policy: } \\
\text { - Networking between the national non- } \\
\text { governmental organization's and the Ministry of } \\
\text { Health. } \\
\text { - National policy and standards on PC and opioids } \\
\text { legislations. } \\
\text { - Baseline data and research. } \\
\text { - Interdisciplinary teamwork. }\end{array}$ \\
\hline $\begin{array}{l}\text { Bingley and Clark [52] } \\
2008 \\
\text { UK }\end{array}$ & $\begin{array}{l}\text { To review PC } \\
\text { development } \\
\text { in six Middle East } \\
\text { countries }\end{array}$ & $\begin{array}{l}\text { Middle East } \\
\text { countries } \\
\text { Cancer }\end{array}$ & $\begin{array}{l}\text { Personal: } \\
\text { - Opioid phobia in the public } \\
\text { - Opioid phobia in professionals } \\
\text { - Lack of public awareness of PC } \\
\text { - Lack of professional level } \\
\text { awareness } \\
\text { Health System: } \\
\text { - Inadequate professional training } \\
\text { programs } \\
\text { Policy: } \\
\text { - Lack of funds } \\
\text { - Lack of government support. }\end{array}$ & $\begin{array}{l}\text { Personal: } \\
\text { - Public education programs; } \\
\text { - Raising awareness about the need for PC } \\
\text { Health System: } \\
\text { - Increasing national and international training } \\
\text { - Improving opioid legislation } \\
\text { Policy: } \\
\text { - Improving health care policies; } \\
\text { - Negotiating for a secure government or health } \\
\text { insurance funding provision }\end{array}$ \\
\hline $\begin{array}{l}\text { McDermott [53] } \\
2007 \\
\text { UK }\end{array}$ & $\begin{array}{l}\text { To identify } \\
\text { strengths and } \\
\text { weaknesses in the } \\
\text { state } \\
\text { of development } \\
\text { across the } \\
\text { subcontinent. }\end{array}$ & $\begin{array}{l}\text { India } \\
\text { Cancer }\end{array}$ & $\begin{array}{l}\text { Personal: } \\
\text { - Limited knowledge of patients } \\
\text { about PC } \\
\text { Health System: } \\
\text { - Unavailability of opioid } \\
\text { - Shortage of workforce } \\
\text { Policy: } \\
\text { - Limited national PC policy } \\
\text { - Insufficient funding for services } \\
\text { - Absence of social security } \\
\text { system } \\
\text { Organisation/ Structure: } \\
\text { - Poverty; } \\
\text { - Population density } \\
\text { - Geography }\end{array}$ & $\begin{array}{l}\text { Personal: } \\
\text { - Increase public awareness of PC } \\
\text { Health System: } \\
\text { - Improve drug availability and expertise } \\
\text { Policy: } \\
\text { - Include PC in medical and nursing curricula } \\
\text { - Design and implement a national PC policy }\end{array}$ \\
\hline
\end{tabular}




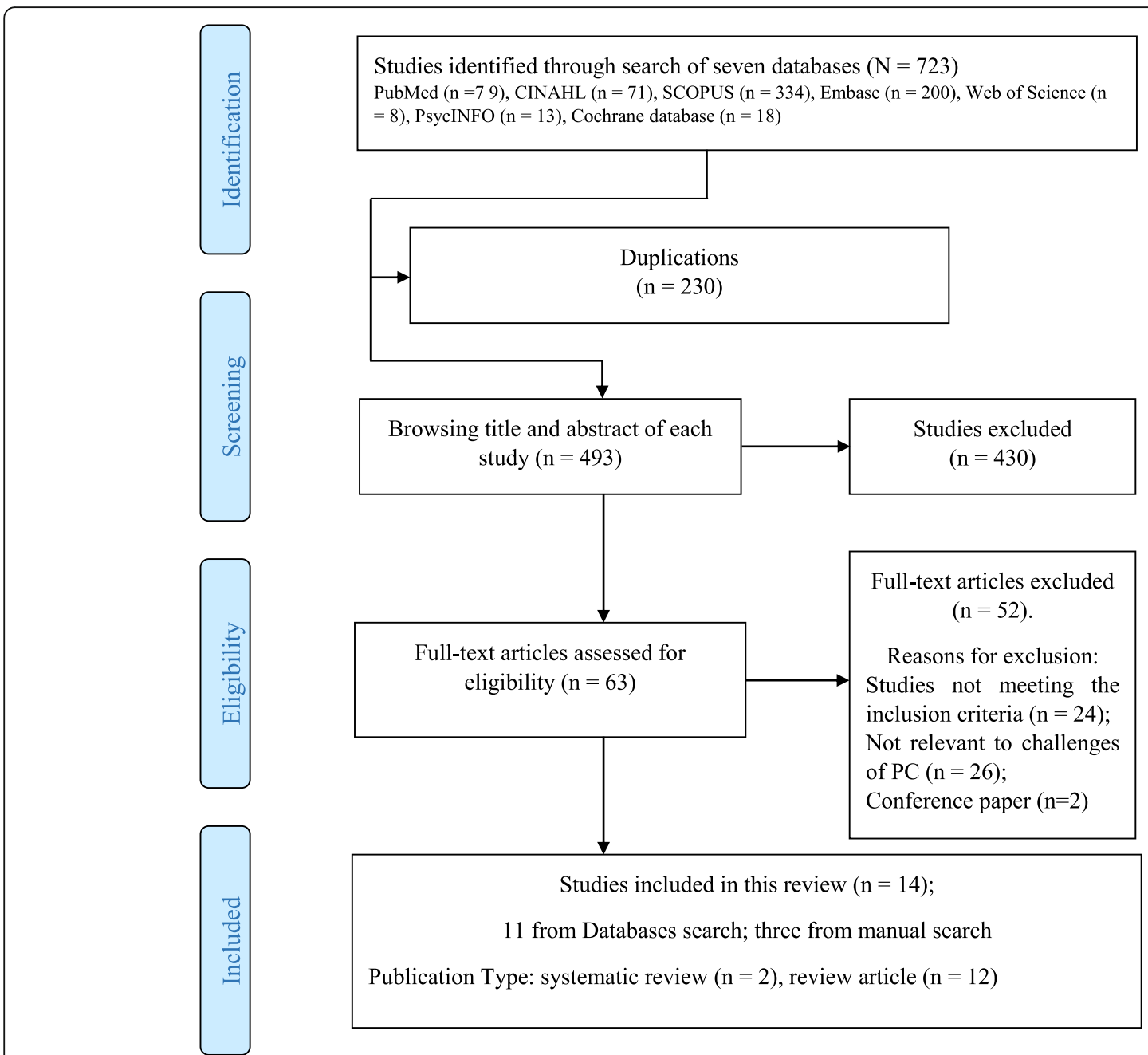

Fig. 2 Flow Diagram of the identification of papers

included in each review, only two reviews included the number of studies in their reviews $[39,48]$; one of them included nine studies [48], and the other [39] included 18 studies. Table 2 displays the characteristics and main findings of all the included reviews.

\section{Quality of the included studies}

Generally, the methodological quality of the narrative reviews was good. Nine narrative reviews scored $\geq 5$ points on the INSA tool, reflecting good quality reviews [32$35,40,46,49,51,52]$. The rest of the reviews $(n=3)$ had a score equal to 4 points on the INSA tool $[47,50,53]$. Half of the narrative reviews did not report a conflict of interest [35, 47, 50-53]. The methodological quality of the systematic reviews $[39,48]$ was high, which suggests a paper presenting an accurate and comprehensive summary of the results of the available studies that address the question of interest.
Challenges to the provision of palliative care Personal challenges

Personal challenges focused on knowledge, attitudes, beliefs, skills, culture of patients and families, the general public and HCPs. Seven reviews [34, 40, 48, 50-53] showed that knowledge deficits of HCPs about PC and the use of opioid analgesics were the most common challenges affecting the provision of PC for cancer patients. Additionally, some patients could not distinguish between $\mathrm{PC}$ and hospice care $[34,48,50,52]$. Five other reviews indicated that HCPs, families, and the general public were poorly aware about PC and its benefits to patients and health-care systems [34, 40, 50-52]. Besides, four reviews pointed to negative attitudes and beliefs among HCPs as obstacles in the provision of PC services [32, 33, 35, 49].

\section{Health care system challenges}

Health care system challenges included workforce development issues, education, service delivery, and access 
issues across organisations. Thirteen reviews discussed the health care system as a barrier to the provision of PC $[32-35,39,40,46,48-53]$. Shortage of or inadequately trained $\mathrm{PC}$ workforce was the most critical barrier to the provision of $\mathrm{PC}[32-35,50]$. This includes a shortage of nursing staff [50], especially the shortage of trained female nurses [32], and few specialised ancillary personnel [32]. Moreover, there was a lack of professional training programmes for HCPs $[46,49-51]$, including the failure to offer basic training to staff [32] and little collaboration/partnership between health organisations [40].

Drug restrictions were also identified as one of the health care system challenges, as reported in seven reviews. These restrictions included inadequate access to essential pain-relief medicines [33, 35, 40, 48, 49], interruption of opioids supply and availability [32, 35], and cumbersome drug importation processes [39].

\section{Organisational challenges}

Organisational level issues shed light on structure, organisational culture, policies, and procedures of the organisation. Four reviews reported organisational-related issues as a barrier to the provision of PC in LMICs [34, 39, 46, 53]. Facilities infrastructure constitute one of the major components of the health care system and this must be estimated and planned before the provision of any services. Limited physical infrastructure (i.e., buildings, equipment and supplies, beds, chairs, etc) were reported as the critical challenges to the provision of PC $[39,46]$. In addition, the geography of the country [48, 53] (i.e., people living in a rural or remote area) could hinder access to PC services [53].

\section{Policy/payment challenges}

Twelve reviews reported key policy challenges (funds, legislation, and research) as factors impeding the provision of PC for cancer patients [32-35, 39, 40, 46, 49-53]. Across five reviews, shortage or lack of funding was recognised as the most critical barrier to the provision of $\mathrm{PC}[34,35,39,52,53]$. Several other studies acknowledged that lack of a comprehensive national PC plan $[40,46,49,51]$, inadequate or inappropriate legislation and policy $[46,51,53]$, fragmented or weak health care system $[39,40]$, and lack of government support [34, 52] negatively impacted on the delivery of PC to cancer patients. Collectively, these identified challenges were influenced by limited political commitment [39], complicated political situations [40], restrictive pharmacovigilance laws and regulations [39], or absence of a state-sponsored social security system [53].
Possible facilitators for the provision of palliative care Of the 14 reviews, 13 mentioned facilitators for overcoming challenges associated with the provision of PC. Personal facilitators were discussed in 11 review articles [32-34, 39, 46, 48-53]. Health care system facilitators were also presented in 11 reviews [32-34, 46-53]. Policy facilitators were enumerated in 12 reviews [32-34, 39, 46-53], while organisational facilitators were discussed in only one review [46].

\section{Personal facilitators}

Reviews indicated that adequate and continuous education is needed for both HCPs and patients and the wider general public [32-34, 39, 46, 48-53] for changing their attitude to PC and improving their awareness of PC [34, 48, 50-52]. Adequate education of the general public and family were covered in 10 reviews [32-34, 39, 46, $48-50,52,53]$, appropriate education of HCPs in four reviews [32-34, 51], improving public and HCPs attitudes on opiophobia in two reviews [34, 49], and enhancement of cultural aspects and providing $\mathrm{PC}$ that valued patient's preferences and beliefs were described in one review [46].

\section{Health care system facilitators}

Facilitators related to the health care system were mentioned in 12 reviews [32-34, 39, 46-53]. Adequate training of HCPs was also identified as a critical health care system facilitator that could not only improve the quality of care but also increase the workforce [32-34, 46, 47, $51,52]$. Moreover, the quality of the workforce can be enhanced through increasing national and international professional programmes $[47,49,51,52]$, providing informal training to medical oncologists [34], creating a supportive learning environment for HCPs and developing information management systems [39], and integrating PC into curricula and practice $[47,49-51,53]$. Other facilitators identified included changing legislation that inappropriately restricts access to opioid medications $[33,46,52,53]$ and improving access to and availability of narcotic drugs $[46,53]$.

\section{Organisational facilitators}

Improving the physical infrastructure of health care settings can play a crucial facilitative role in the development and provision of $\mathrm{PC}$, as reported in two reviews $[46,51]$.

\section{Policy/payment facilitators}

Policy/payment issues were the main facilitators to the provision of PC for cancer patients, as described in 12 reviews [32-34, 39, 46-53]. Designing and implementing a national PC policy were the main facilitators discussed in nine reviews $[33,39,46-49,51-53]$. These can be 
achieved through the involvement of stakeholders [39], budget support [33, 34, 39, 47, 50], and negotiating for secure government or health insurance funding provision [52]. Enhancing and increasing research about PC were also identified as essential policy facilitators $[32,46,50,51]$, which help in identifying the needs and gaps in the provision of PC.

\section{Discussion}

This systematic review adds to the literature on the topic by providing a systematic and more comprehensive mapping of the challenges associated with the provision of PC services in LMICs. This goes further to identify some common facilitators to overcome these challenges in LMICs. Fourteen reviews have highlighted that the provision of PC for cancer patients in LMICs are affected by a wide range of challenges. Personal and health care system-related issues have been highlighted as key challenges to the provision of PC. One interesting finding was that although the included reviews focused on LMICs, seven authors who conducted these reviews were from developed countries, indicating the interest from developed countries about PC in countries with minimal resources and in developing economies.

Overall, insufficient knowledge, poor awareness, negative attitudes and beliefs of patients, families, the general public, and HCPs are crucial personal challenges to the provision of PC in LMICS. Four reviews that were conducted in developed countries [41,56-58] reported similar findings. Furthermore, a population-based study suggests that a low level of awareness and knowledge deficit common among adults are part of the challenges [59]. Another study linked insufficient knowledge and low level of awareness of patients, families, the public, and HCPs to PC services and their benefits [60] to these challenges, potentially contributing to delayed referrals of patients to PC services [61-63]. Therefore, PC education has been recommended as the first step [64] to increase awareness, promote positive attitudes and improve knowledge about these services among the general public and HCPs [65-67]. This can be realised through integration of core competencies of PC into the curricula of universities $[64,68]$ and cultivating more positive attitudes in the general public through the media or public engagement programmes.

The results of this review indicate that shortages of or inadequately trained workforce, and poor accessibility and availability of pain-relief medication are essential health care system challenges to the provision of PC. There is a significant shortage of specialised HCPs in the PC world $[69,70]$. This shortage will affect the quality of the PC services provided [71] and the fulfilment of expectations of cancer patients [71]. Investment in terms of time and resources in the training of competent a PC workforce is a recommended facilitator in addressing the workforce shortages. Also, volunteers can play crucial roles in supporting the health of cancer patients and overcoming workforce shortages [72, 73]. There are benefits in involving and utilising volunteers in health settings. They can be used for caring and delivering support and services to patients and the overall economy of the health care system [74, 75]. Using volunteers to improve psychosocial health, education, and engagement might be an effective way for lowering costs and the economic burden of delivering PC services in LMICs [76]. Volunteers, however, require effective and appropriate training to enhance their performance and the quality of care provided to patients $[38,77]$. This has been successfully implemented in some LMICs [78].

Poor accessibility of pain-relieving medications is a unique barrier to accessing PC in LMICs, with $80 \%$ of people having little or no access to such medication [38]. Despite the availability of pain-relieving medications as a basic component of health care systems, false perceptions of patients and their families [79-82] and HCPs $[83,84]$ can be major challenges to the provision of PC. Many patients avoid using pain-relieving medication because of their belief and fear that the use of this medication will lead to addiction [79-82]. While HCPs may not prefer to prescribe these medications because of their lack of adequate pain assessment skills and their beliefs also that the use of opioids can cause addiction [83, 84]. Besides the perceptions of patients and HCPs about the use of opioids, it is further acknowledged that developing countries constitute $80 \%$ of the world population but receive only $6 \%$ of the available morphine [85]. The European Society of Medical Oncology, through its Global Opioid Policy Initiative project, has identified a range of issues impacting the use of opioids in LMICs, and these include not only unavailability of opioids, but also outdated policies that discourage access, limited awareness and unnecessary administrative obstacles, and inadequate education and empowerment of HCPs [86]. Often it is a combination of all above factors that impede the use and uptake of opioids in LMICs making access to such medication a complex issue. Several authors recognise the worldwide lack of access to opioids [87-89] as a factor affecting the provision of PC to cancer patients. Furthermore, for PC to become readily available, restrictions on the access to opioid drugs in LMICs should be removed [90]. This is because opioid therapy requires both availability and affordability for cancer patients while receiving $\mathrm{PC}$, as pain management is one of the critical components in PC services [64, 84]. A few authors opine that the availability and affordability of opioids are essentially part of "human rights" [91, 92], and WHO has developed a list of essential medicines for a basic healthcare system, including opioids and 
medicines for other common symptoms in PC [93]. Legal restrictions, such as national laws often restrict opioid use or prohibit access to narcotics [87, 89, 94, 95]. These impediments, nonetheless, have negative consequences on patients and their families [96]. Reviewing or changing related legislation and policies are needed to overcome these impediments. This can be carried out at the national level by analysing legislation and policy documents [87, 95, 97].

Limited physical infrastructure, in addition to the geography of the country, poverty, and population density are the main organisational challenges to the provision of PC. Developing countries experience financial/funding challenges and poverty, which negatively affect the development of their health care systems [98]. Therefore, it is recommended that policy makers collaborate with national and international organisations to secure funding for improving health care provision.

Most people in need of PC are at home due to transportation difficulties or limited income to with accessing care or buying medication [99]. Integrating PC into primary care services is a recommended strategy to improve access to $\mathrm{PC}$ for patients living in remote areas [100]. This integration will help patients and their families, who are living in remote areas, to receive comprehensive care without being overwhelmed by personal cost issues [101].

Shortage of funding and lack of a comprehensive national plan on implementing $\mathrm{PC}$ that are identified in this review are complex and overlapping. Lack of national plans and policies on the provision of PC services are common in most developing countries [28]. LMICs should develop national PC plans and integrate these plans within their strategy for non-communicable diseases. This should be in line with the local context and health care needs and can be achieved through engagement of policy makers and budget estimations [102]. There was also lack of cost data available in the included reviews and previous literature which is also considered a barrier to introducing and estimating PC cost. In the reviews assessed, most LMICs only briefly highlighted the insufficient funding and limited-resources, although availability of funding is of paramount importance in the development of PC services.

For overcoming policy challenges, policy makers should understand the processes involved in PC implementation, factors that affect implementation and the introduction of solutions for overcoming these obstacles [103]. Credible setting of policy agendas, realistic policy formulation, timely policy implementation, and policy monitoring and evaluation [104] remain pressing needs of LMICs for overcoming these impediments. Involving policy makers in this process is essential and has a significant positive effect on defining their priorities, diagnosing their challenges, and implementing appropriate solutions for service improvement [105].

Challenges that hinder the provision of PC differ significantly in developed and developing countries in terms of scope, context, culture, and religious beliefs. However, there are some similarities in challenges to PC provision. The main common obstacles to the provision of PC in both developed countries and LMICs include lack of a properly trained workforce [41, 56-58], fear among HCPs [106, 107], lack of awareness about PC [59, $60,108-110]$, limited funding and lack of coordination amongst services [106]. However, in developing countries, factors affecting the provision of PC services to cancer patients further include lack of resources and inadequate physical infrastructure. Others are related to administrative challenges, which are mainly centred on access to opioids and organisational commitment [31]. Furthermore, culture, beliefs, and norms about death and opioid consumption are working against PC in LMICs. Compared to developed countries, inadequate accessibility and availability of opioids are unique to developing countries.

About $83 \%$ of people in developing countries consume only $9 \%$ of the world morphine available [111], in comparison with $7.5 \%$ of the countries located in the American and European Regions that have adequate consumption levels of opioids [112]. A lower percentage of consumption of opioids in developing countries may be tied to the legislation in some countries whereby patients are required to register to receive opioids. In fact, some African and European countries even require special registration for hospice patients [87, 95].

Negative attitudes about PC and death, opioid phobia, and families' feeling of alienation and isolation are the most common challenges in developing countries, while, misperceptions equating "PC" with end-of-life care of HCPs and the general public are the main challenges in developed countries [41, 56-58]. Furthermore, in developed countries, PC is provided relatively well for cancer patients, and most patients enjoy good access to services [31]. Nevertheless, uneven PC coverage [106] is most common in countries with low-resources.

Future research efforts are needed to develop a body of evidence that is adequate to support effective learning and policy development. Furthermore, other potential challenges that may hinder the provision of $\mathrm{PC}$ that have not been covered in this review may form the basis for future studies. For instance, two significant aspects may be considered. The first aspect is the HCP's voice. As most reviews have focused on knowledge, attitudes, and beliefs, none has investigated communication competencies between HCPs and their relationship with their patients, an important aspect for the successful provision of PC. Communicating professionally with patients 
improves their attitudes [113-115]. The second aspect is the patients'/family voice. Most reviews have examined the attitudes of patients and their families towards PC services, but none studied the priorities, needs, and wishes of patients about PC services in LMICs. For policy development, assessing the country readiness for the provision and integration of $\mathrm{PC}$ is an essential step to an effective adoption [116].

\section{Strengths and limitations}

A strength of this systematic review is that it covered several databases, with up to date data to capture information more relevant to current health care systems. However, this review also presents with several limitations, such as limited number of original studies included in the reviews, focusing only on reviews, and the narrative format of most reviews used in the present analysis.

\section{Conclusion}

This review expands the existing knowledge about challenges and possible facilitators on the provision of $\mathrm{PC}$ services for cancer patients in LMICs. Understanding these challenges from each level (from policy and organisation down to individual patient-health care providers) could help in the development of PC pathways in LMICs and it could be used as a guide to develop a model for the provision of PC services. It can be used by policy makers to understand the implementation of a new PC programme in their countries and the areas they need to focus on and prioritise. It can be used by nongovernmental organisations to supplement governmental efforts and cover related gaps. Also, political influence and support are required to ensure sustainability and high-quality PC services. Although PC for patients with cancer is gaining gradual recognition worldwide [24], it still lacks widespread adoption in LMICs. Overall, this detailed analysis of challenges and possible facilitators' offers the opportunity to develop interventions to improve and implement PC into health care systems in LMICs.

\section{Abbreviations \\ AMSTAR: Assessment of Multiple Systematic Reviews; CINAHL: Cumulative Index to Nursing and Allied Health Literature; MECs: Middle East Countries; HCPs: Health Care Providers; INSA: International Narrative Systematic Assessment; LMICs: Low- and Middle-Income Countries; MeSH: Medical Subject Heading; PC: Palliative Care; PRISMA: Preferred Reporting Items for Systematic Reviews and Meta-Analyses; QOL: Quality of Life; SEM: Socio- Ecological Model; UK: United Kingdom; USA: United State America}

\section{Acknowledgments}

Not applicable.

\section{Authors' contributions}

Study design, literature search, data extraction, and checking, data synthesis and interpretation, and manuscript drafting and revision: HAB and AM; Study conception and design, and manuscript revision: AM and JL. Data extraction and checking, and manuscript revision: $\mathrm{HAB}, \mathrm{AM}, \mathrm{JL}$. Drafting initial paper: $\mathrm{HAB}$; Contribution in the discussion and final write-up: All authors; All authors approved the final manuscript.

\section{Funding}

No funding was obtained for this study.

\section{Availability of data and materials}

Data used for analysis in this review are all extracted from the original published reviews and are presented in Table 2 (Summary of the included reviews' aims and key findings).

\section{Ethics approval and consent to participate}

Not applicable.

\section{Consent for publication \\ Not applicable.}

\section{Competing interests}

The researchers declare that there is no conflict of interests regarding the publication of this paper.

Received: 25 July 2019 Accepted: 6 April 2020

Published online: 22 April 2020

\section{References}

1. American Cancer Society: Cancer facts \& figures 2018. 250 Williams Street, NW, Atlanta, GA h8; 2018.

2. Bray F, Ferlay J, Soerjomataram I, Siegel RL, Torre LA, Jemal A. Global cancer statistics 2018: GLOBOCAN estimates of incidence and mortality worldwide for 36 cancers in 185 countries. CA Cancer J Clin. 2018:68(6):394-424.

3. World Health Organization: Cancer. PRESS RELEASE N² 263.; 2018.

4. World Bank Group: World Bank country and lending groups: country classification. 2017.[https://datahelpdesk.worldbank.org/knowledgebase/ articles/906519-world-bank-country-and-lending-groups]. Accessed 22 Feb 2019

5. Tefferi A, Kantarjian H, Rajkumar SV, Baker LH, Abkowitz JL, Adamson JW, Advani RH, Allison J, Antman KH, Bast RC Jr, et al. In support of a patientdriven initiative andpetition to lower thehigh price of cancer drugs. Mayo Clin Proc. 2015;90(8):996-1000.

6. International Atomic Energy Agency: World cancer day 2019 - boosting capacity for cancer care 2019.

7. Prager GW, Braga S, Bystricky B, Qvortrup C, Criscitiello C, Esin E, Sonke GS, Martínez GA, Frenel J-S, Karamouzis M, et al. Global cancer control: responding to the growing burden, rising costs and inequalities in access. ESMO Open. 2018:3(2):e000285.

8. Surbone A, Baider L, Weitzman T, Brames M, Rittenberg C, Johnson J. Psychosocial care for patients and their families is integral to supportive care in cancer: MASCC position statement. Support Care Cancer. 2010;18(2): 255-63.

9. Gysels M, Higginson I, Rajasekaran M, Davies E, Harding R. Improving supportive and palliative care for adults with cancer: research evidence. National Institute for Health and Clinical Excellence; 2004.

10. Holland JC. American Cancer Society Award lecture. Psychological care of patients: psycho-oncology's contribution. J Clin Oncol. 2003;21(23 Suppl): 253s-65s.

11. Pérez-Cruz PE, Langer $P$, Carrasco C, Bonati $P$, Batic B, Tupper Satt $L$, Gonzalez Otaiza M. Spiritual pain is associated with decreased quality of life in advanced cancer patients in palliative care: an exploratory study. J Palliat Med. 2019;22(6):663-9.

12. World Health Organization: Definition of palliative care. Geneva; 2002; 2017.

13. World Health Organization. National cancer control programmes: policies and managerial guidelines. 2nd ed. Geneva: World Health Organization; 2002. p. 84 .

14. Gomez-Batiste X, Stjernsward J, Espinosa J, Martinez-Munoz M, Trelis J, Constante C. How to design and implement palliative care public health programmes: foundation measures. An operational paper by the $\mathrm{WHO}$ collaborating Centre for Public Health Palliative Care Programmes at the Catalan Institute of Oncology. BMJ Support Palliat Care. 2013;3(1):18-25.

15. Stjernsward J, Foley KM, Ferris FD: The public health strategy for palliative care 2007, 33(5):486-493. 
16. Kaye EC, Rubenstein J, Levine D, Baker JN, Dabbs D, Friebert SE. Pediatric palliative care in the community. CA Cancer J Clin. 2015;65(4):316-33.

17. Centeno-Cortes C, Lynch T, Donea O, Rocafort J, Clark D. EAPC atlas of palliative care in Europe 2013-full edition; 2013.

18. Morrison RS, Meier DE. Palliative care. N Engl J Med. 2004;350(25):2582-90 +2629 .

19. Zimmermann C, Swami N, Krzyzanowska M, Hannon B, Leighl N, Oza A, Moore M, Rydall A, Rodin G, Tannock I, et al. Early palliative care for patients with advanced cancer: a cluster-randomised controlled trial. Lancet. 2014; 383(9930):1721-30.

20. Numico G, Cristofano A, Mozzicafreddo A, Cursio OE, Franco P, Courthod G, Trogu A, Malossi A, Cucchi M, Sirotovà Z, et al. Hospital admission of cancer patients: avoidable practice or necessary care? PLoS One. 2015;10(3): e0120827.

21. Cassel EJ. The nature of suffering and the goals of medicine. N Engl J Med. 1982;306(11):639-45

22. Abu Hamad B, Skaik N, Abu-Odah H. Evaluation of palliative care services provided to cancer patients in the Gaza strip. J US-China Medical Sci. 2016; 13(2016):95-107.

23. Mercadante S, Masedu F, Valenti M, Mercadante A, Aielli F. The characteristics of advanced cancer patients followed at home, but admitted to the hospital for the last days of life. Intern Emerg Med. 2016;11(5):713-8.

24. Worldwide Palliative Care Alliance, World Health Organization. Global atlas of palliative care at the end of life. London: Worldwide Palliative Care Alliance; 2014

25. Morris K. Cancer? In Africa? Lancet Oncol. 2003;4(1):5-5

26. Chan M. Cancer in developing countries: facing the challenge. In: Address at the IAEA Scientific Forum, vol. 2010; 2010.

27. Halahleh K, Gale RP. Cancer care in the Palestinian territories. Lancet Oncol. 2018;19(7):e359-64.

28. Ddungu $\mathrm{H}$. Palliative care: what approaches are suitable in developing countries? Br J Haematol. 2011;154(6):728-35.

29. Sachedina A. End-of-life: the Islamic view. Lancet. 2005;366(9487):774-9.

30. Sarhill N, LeGrand S, Islambouli R, Davis MP, Walsh D. The terminally ill Muslim: death and dying from the Muslim perspective. Am J Hosp Palliat Care. 2001;18(4):251-5.

31. Hawley P. Barriers to access to palliative care. Palliative care. 2017;10: 1178224216688887

32. Abdel-Razeq H, Attiga F, Mansour A. Cancer care in Jordan. Hematol Oncol Stem Cell Ther. 2015;8(2):64-70.

33. Hannon B, Zimmermann C, Knaul FM, Powell RA, Mwangi-Powell FN, Rodin G. Provision of palliative care in low- and middle-income countries: overcoming obstacles for effective treatment delivery. J Clin Oncol. 2016; 34(1):62-8.

34. Zeinah GF, Al-Kindi SG, Hassan AA. Middle East experience in palliative care. Am J Hosp Palliat Care. 2013;30(1):94-9.

35. Basu A, Mittag-Leffler BN, Miller K. Palliative care in low- and mediumresource countries. Cancer J. 2013;19(5):410-3.

36. World Health Organization: Strengthening of palliative care as a component of comprehensive care throughout the life course; the Sixty-seventh World Health Assembly. 2014.

37. Saini S, Bhatnagar S. Cancer pain management in developing countries. Indian J Palliat Care. 2016:22(4):373-7.

38. Knaul FM, Frenk J, Shulman L. Closing the cancer divide: a blueprint to expand access in low and middle income countries. Boston: Harvard Global Equity Initiative; 2011.

39. Donkor A, Luckett T, Aranda S, Phillips J. Barriers and facilitators to implementation of cancer treatment and palliative care strategies in lowand middle-income countries: systematic review. Int J Public Health. 2018; 63(9):1047-57

40. Fadhil I, Lyons G, Payne S. Barriers to, and opportunities for, palliative care development in the eastern Mediterranean region. Lancet Oncol. 2017;18(3): e176-84.

41. Aldridge MD, Hasselaar J, Garralda E, van der Eerden M, Stevenson D, McKendrick K, Centeno C, Meier DE. Education, implementation, and policy barriers to greater integration of palliative care: a literature review. Palliat Med. 2016:30(3):224-39.

42. McLeroy KR, Bibeau D, Steckler A, Glanz K. An ecological perspective on health promotion programs. Health Educ Q. 1988;15(4):351-77.
43. Golden SD, Earp JA. Social ecological approaches to individuals and their contexts: twenty years of health education \& behavior health promotion interventions. Health Educ Behav. 2012;39(3):364-72.

44. Ma PHX, Chan ZCY, Loke AY. The socio-ecological model approach to understanding barriers and facilitators to the accessing of health services by sex workers: a systematic review. AIDS Behav. 2017;21(8):2412-38.

45. Moher D, Liberati A, Tetzlaff J, Altman DG. Preferred reporting items for systematic reviews and meta-analyses: the PRISMA statement. PLoS Med. 2009;6(7):e1000097.

46. Soto-Perez-de-Celis E, Chavarri-Guerra Y, Pastrana T, Ruiz-Mendoza R, Bukowski A, Goss PE. End-of-life care in Latin America. J Glob Oncol. 2017:3(3):261-70.

47. Ali Z. Kenya hospices and palliative care association: integrating palliative care in public hospitals in Kenya. Ecancermedicalscience. 2016;10:655.

48. Rochmawati E, Wiechula R, Cameron K. Current status of palliative care services in Indonesia: a literature review. Int Nurs Rev. 2016;63(2):180-90.

49. Silbermann M, Arnaout M, Daher M, Nestoros S, Pitsillides B, Charalambous $H$, Gultekin M, Fahmi R, Mostafa KA, Khleif AD, et al. Palliative cancer care in middle eastern countries: accomplishments and challenges. Ann Oncol. 2012;23(Suppl 3):15-28.

50. Elcigil A: The current status of palliative care in Turkey: a nurse's perspective. J Pediatr Hematol Oncol 2011, 33 Suppl 1(SUPPL. 1):S70-S72.

51. Shawawra M, Khleif AD. Palliative care situation in Palestinian authority. J Pediatr Hematol Oncol. 2011;33(Suppl 1):S64-7.

52. Bingley A, Clark D. A comparative review of palliative care development in six countries represented by the Middle East Cancer consortium (MECC). J Pain Symptom Manag. 2009;37(3):287-96.

53. McDermott E, Selman L, Wright M, Clark D. Hospice and palliative care development in India: a multimethod review of services and experiences. J Pain Symptom Manag. 2008;35(6):583-93.

54. La Torre G, Backhaus I, Mannocci A: Rating for narrative reviews: concept and development of the International Narrative Systematic Assessment tool. 2015. [https://sensesandsciences.com/index.php/Senses/article/view/52] Accessed 2 Feb. 2019

55. Shea BJ, Reeves BC, Wells G, Thuku M, Hamel C, Moran J, Moher D, Tugwell $P$, Welch V, Kristjansson E, et al. AMSTAR 2: a critical appraisal tool for systematic reviews that include randomised or non-randomised studies of healthcare interventions, or both. BMJ. 2017;358:j4008.

56. LeBlanc TW, Roeland EJ, El-Jawahri A. Early palliative care for patients with hematologic malignancies: is it really so difficult to achieve? Curr Hematol Malig Rep. 2017;12(4):300-8.

57. Dalgaard KM, Bergenholtz H, Nielsen ME, Timm H. Early integration of palliative care in hospitals: a systematic review on methods, barriers, and outcome. Palliat Support Care. 2014;12(6):495-513.

58. Davies P, Prince-Paul M. Palliative Care in the Outpatient Cancer Center: current trends. J Hosp Palliat Nurs. 2012;14(8):506-15.

59. Shalev A, Phongtankuel V, Kozlov E, Shen MJ, Adelman RD, Reid MC. Awareness and misperceptions of hospice and palliative care: a populationbased survey study. Am J Hosp Palliat Care. 2018;35(3):431-9.

60. Lane T, Ramadurai D, Simonetti J. Public awareness and perceptions of palliative and comfort care. Am J Med. 2019;132(2):129-31.

61. Ryan T, Ingleton C. Most hospices and palliative care programmes in the USA serve people with dementia; lack of awareness, need for respite care and reimbursement policies are the main barriers to providing this care. Evid Based Nurs. 2011;14(2):40-1.

62. Torke AM, Holtz LR, Hui S, Castelluccio P, Connor S, Eaton MA, Sachs GA. Palliative care for patients with dementia: a national survey. J Am Geriatr Soc. 2010;58(11):2114-21.

63. Cherny N. Stigma associated with "palliative care" getting around it or getting over it. Cancer. 2009;115(9):1808-12.

64. World Health Organization. Strengthening of palliative care as a component of integrated treatment within the continuum of care. J Pain Palliat Care Pharmacother. 2014;28(2):130-4.

65. Zelko E, Selic P, Malacic S. Palliative care: a cross sectional study focused on different capacity building programmes evaluated through self-rated knowledge and efficiency in family medicine tutors. Materia socio-medica. 2017:29(2):114.

66. Fischer SM, Gozansky WS, Kutner JS, Chomiak A, Kramer A. Palliative care education: an intervention to improve medical residents' knowledge and attitudes. J Palliat Med. 2003;6(3):391-9 
67. Dalberg T, McNinch NL, Friebert S. Perceptions of barriers and facilitators to early integration of pediatric palliative care: a national survey of pediatric oncology providers. Pediatr Blood Cancer. 2018;65(6):e26996.

68. Stjernswärd J, Foley KM, Ferris FD. The public health strategy for palliative care. J Pain Symptom Manag. 2007;33(5):486-93.

69. Kamal AH, Maguire JM, Meier DE. Evolving the palliative care workforce to provide responsive, serious illness care. Ann Intern Med. 2015;163(8):637-8.

70. Canadian Medical Association: Palliative care: Canadian medical association's national call to action —examples of innovative care delivery models, training opportunities and physician leaders in palliative care. 2015; 2015.

71. Lupu D. American Academy of hospice and palliative medicine workforce task force: estimate of current hospice and palliative medicine physician workforce shortage. J Pain Symptom Manag. 2010;40(6):899-911.

72. Centeno C, Bolognesi D, Biasco G. Comparative analysis of specialization in palliative medicine processes within the World Health Organization European region. J Pain Symptom Manag. 2015;49(5):861-70.

73. Carrasco JM, Lynch TJ, Garralda E, Woitha K, Elsner F, Filbet M, Ellershaw JE Clark D, Centeno C. Palliative care medical education in European universities: a descriptive study and numerical scoring system proposal for assessing educational development. J Pain Symptom Manage. 2015;50(4): 516-23 e512.

74. Frick KD, Carlson MC, Glass TA, McGill S, Rebok GW, Simpson C, Fried LP. Modeled cost-effectiveness of the experience corps Baltimore based on a pilot randomized trial. J Urban Health. 2004;81(1):106-17.

75. International Labour Organization: Manual on the measurement of volunteer work; 2011.

76. Sales VL, Ashraf MS, Lella LK, Huang J, Bhumireddy G, Lefkowitz L, Feinstein M, Kamal M, Caesar R, Cusick E, et al. Utilization of trained volunteers decreases 30-day readmissions for heart failure. J Card Fail. 2013;19(12):84250.

77. Knaul FM, Farmer P, Krakauer EL, De Lima L, Bhadelia A, Kwete XJ, ArreolaOrnelas H, Gómez-Dantés O, Rodriguez NM, Alleyne GA. Alleviating the access abyss in palliative care and pain relief-an imperative of universal health coverage: the lancet commission report. Lancet. 2018;391(10128): $1391-454$.

78. Steedman MR, Hughes-Hallett T, Knaul FM, Knuth A, Shamieh O, Darzi A. Innovation can improve and expand aspects of end-of-life care in low- and middle-income countries. Health Aff. 2014:33(9):1612-9.

79. Krakauer EL, Wenk R, Buitrago R, Jenkins P, Scholten W. Opioid inaccessibility and its human consequences: reports from the field. J Pain Palliat Care Pharmacother. 2010;24(3):239-43.

80. Jemal A, Center MM, DeSantis C, Ward EM. Global patterns of cancer incidence and mortality rates and trends. Cancer Epidemiology Prevention Biomarkers. 2010;19(8):1893-907.

81. Bagçivan G, Tosun N, Kömürcü S, Özet A, NJJoCO A. Analysis of the patientrelated barriers in cancer pain anagement in Turkish patients. J Pain Symptom Manage. 2009;27(15_suppl):e20699.

82. Kim YC, Ahn JS, Calimag MMP, Chao TC, Ho KY, Tho LM, Xia ZJ, Ward L, Moon $\mathrm{H}$. Current practices in cancer pain management in Asia: a survey of patients and physicians across 10 countries. J Cancer medicine. 2015;4(8): 1196-204.

83. Peker L, Celebi N, Canbay O, Sahin A, Cakir B, Uzun S, Aypar U. Doctors' opinions, knowledge and attitudes towards cancer pain management in a university hospital. J Turkish Soc Algology. 2008;20(2):20-30.

84. De Lima L, Pastrana T, Radbruch L, Wenk R. Cross-sectional pilot study to monitor the availability, dispensed prices, and affordability of opioids around the globe. J Pain Symptom Manage. 2014;48(4):649-59 e641.

85. Bond M. Availability and accessibility of opioids in developing countries, with special reference to Eastern Europe. Eur Oncology. 2009:5(1):17-8.

86. Cherny NI, Cleary J, Scholten W, Radbruch L, Torode J. The Global Opioid Policy Initiative (GOPI) project to evaluate the availability and accessibility of opioids for the management of cancer pain in Africa, Asia, Latin America and the Caribbean, and the Middle East: introduction and methodology. Ann Oncol. 2013;24(Suppl 11):xi7-13.

87. Cherny NI, Baselga J, de Conno F, Radbruch L. Formulary availability and regulatory barriers to accessibility of opioids for cancer pain in Europe: a report from the ESMO/EAPC opioid policy initiative. Ann Oncol. 2010;21(3): 615-26.

88. Husain SA, Brown MS, Maurer MA. Do national drug control laws ensure the availability of opioids for medical and scientific purposes? Bull World Health Organ. 2014;92(2):108-16.
89. Cleary J, Radbruch L, Torode J, Cherny NI. Next steps in access and availability of opioids for the treatment of cancer pain: reaching the tipping point? Ann Oncol. 2013;24(Suppl 11):xi60-4.

90. Dalal S, Bruera E. Access to opioid analgesics and pain relief for patients with cancer. Nat Rev Clin Oncol. 2013;10(2):108.

91. Brennan F. Palliative care as an international human right. J Pain Symptom Manag. 2007;33(5):494-9.

92. Radbruch L, Payne S, de Lima L, Lohmann D. The Lisbon challenge: acknowledging palliative care as a human right. J Palliat Med. 2013;16(3): $301-4$.

93. World Health Organization. WHO model lists of essential medicines, vol. 2019; 2019.

94. Manjiani D, Paul DB, Kunnumpurath S, Kaye AD, Vadivelu N. Availability and utilization of opioids for pain management: global issues. Ochsner J. 2014; 14(2):208-15.

95. Cleary J, Powell RA, Munene G, Mwangi-Powell FN, Luyirika E, Kiyange F, Merriman A, Scholten W, Radbruch L, Torode J, et al. Formulary availability and regulatory barriers to accessibility of opioids for cancer pain in Africa: a report from the Global Opioid Policy Initiative (GOPI). Ann Oncol. 2013; 24(Suppl 11):xi14-23.

96. Reville B, Foxwell AM. The global state of palliative care-progress and challenges in cancer care. Ann Palliative Med. 2014;3(3):129-38.

97. Bosnjak S, Maurer MA, Ryan KM, Leon MX, Madiye G. Improving the availability and accessibility of opioids for the treatment of pain: the international pain policy fellowship. Support Care Cancer. 2011;19(8):123947.

98. Moore E: How can we improve access to healthcare in emerging countries? 2015.[https://www.weforum.org/agenda/2015/11/how-can-we-improveaccess-to-healthcare-in-emerging-countries/]. Accessed 22 Mar. 2019.

99. World Health Organization: Why palliative care is an essential function of primary health care; 2018.

100. Recoche K, Lee S, O'Connor M, Ross-Heazlewood M, Doherty V, Hood K. Building palliative care capacity in rural health: a collaborative approach. Aust Nurs Midwifery J. 2014;21(10):38.

101. McCormick E, Chai E, Meier DE. Integrating palliative care into primary care. Mt Sinai J Med. 2012;79(5):579-85.

102. World Health Organization: Innovative care for chronic conditions: Building blocks for actions: global report. 2002. 2016

103. Nilsen P. Making sense of implementation theories, models and frameworks. Implement Sci. 2015;10(1):53.

104. Exworthy M. Policy to tackle the social determinants of health: using conceptual models to understand the policy process. Health Policy Plan. 2008;23(5):318-27

105. Bate P, Robert GJBQ. Safety: experience-based design: from redesigning the system around the patient to co-designing services with the patient. Qual Saf Health Care. 2006;15(5):307-10.

106. Lynch T, Clark D, Centeno C, Rocafort J, de Lima L, Filbet M, Hegedus K, Belle $\mathrm{O}$, Giordano A, Guillen F, et al. Barriers to the development of palliative care in Western Europe. Palliat Med. 2010;24(8):812-9.

107. Bhadra K, Manir KS, Adhikary A, Kumar G, Manna A, Sarkar SK. Awareness of palliative care among doctors of various departments in all four teaching medical colleges in a metropolitan city in eastern India: a survey. J Educ Health Promot. 2015;4:20.

108. Mcllfatrick S, Hasson F, McLaughlin D, Johnston G, Roulston A, Rutherford L, Noble H, Kelly S, Craig A, Kernohan WG. Public awareness and attitudes toward palliative care in Northern Ireland. BMC Palliative Care. 2013;12(1):34.

109. Westerlund C, Tishelman C, Benkel I, Fürst CJ, Molander U, Rasmussen BH, Sauter S, Lindqvist O. Public awareness of palliative care in Sweden. Scand J Public Health. 2018;46(4):478-87.

110. Alkhudairi H. General public awareness, knowledge, and beliefs toward palliative care in a Saudi population. J Nature Sci Med. 2019;2(1):48-53.

111. Seya MJ, Gelders SF, Achara OU, Milani B, Scholten WK. A first comparison between the consumption of and the need for opioid analgesics at country, regional, and global levels. J Pain Palliat Care Pharmacother. 2011 25(1):6-18.

112. Duthey B, Scholten W. Adequacy of opioid analgesic consumption at country, global, and regional levels in 2010, its relationship with development level, and changes compared with 2006. J Pain Symptom Manag. 2014;47(2):283-97.

113. Brock D, Abu-Rish E, Chiu C-R, Hammer D, Wilson S, Vorvick L, Blondon K Schaad D, Liner D, Zierler B. Interprofessional education in team 
communication: working together to improve patient safety. Postgrad Med J. 2013;22(5):414-23.

114. Fallowfield $L$, Jenkins V. Effective communication skills are the key to good cancer care. Eur J Cancer. 1999;35(11):1592-7.

115. Perloff RM, Bonder B, Ray GB, Ray EB, Siminoff LA. Doctor-patient communication, cultural competence, and minority health: theoretical and empirical perspectives. Am Behav Sci. 2006;49(6):835-52.

116. Helfrich CD, Li YF, Sharp ND, Sales AE. Organizational readiness to change assessment (ORCA): development of an instrument based on the promoting action on research in health services (PARIHS) framework. Implement Sci. 2009;4(1):38

\section{Publisher's Note}

Springer Nature remains neutral with regard to jurisdictional claims in published maps and institutional affiliations.

Ready to submit your research? Choose BMC and benefit from:

- fast, convenient online submission

- thorough peer review by experienced researchers in your field

- rapid publication on acceptance

- support for research data, including large and complex data types

- gold Open Access which fosters wider collaboration and increased citations

- maximum visibility for your research: over $100 \mathrm{M}$ website views per year

At BMC, research is always in progress.

Learn more biomedcentral.com/submissions 